\author{
DEPARTMENT OF THE INTERIOR \\ UNITED STATES GEOLOGICAL SURVEY
}

\title{
AEROMAGNETIC AND GENERALIZED GEOLOGIC MAP OF THE SAN ANTONIO MOUNTAINS, NEVADA By
}

W. E. Davis, F. J. Kleinhampl and J. I. Ziony
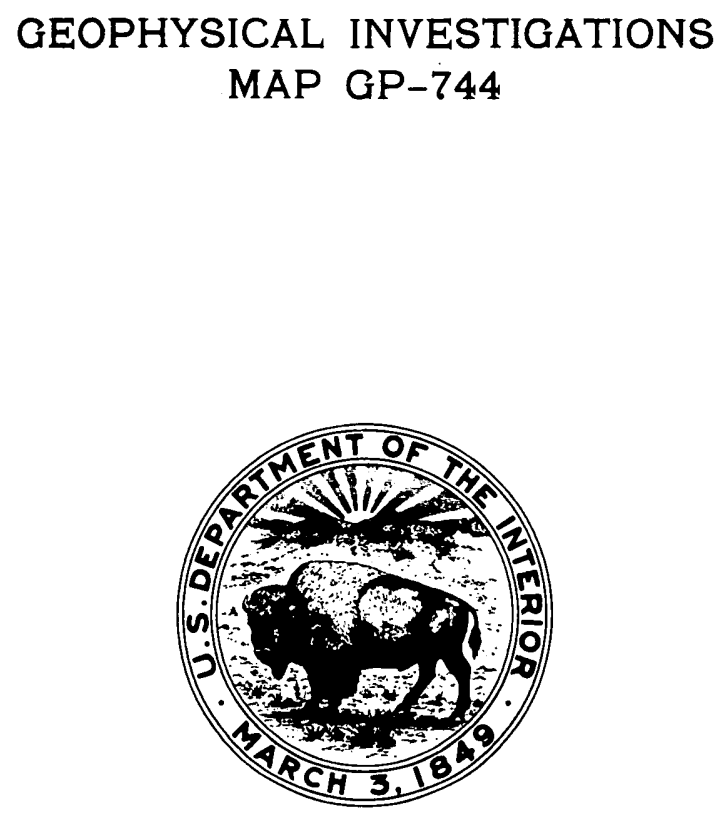


\author{
AEROMAGNETIC AND GENERALIZED GEOLOGIC MAP \\ OF THE SAN ANTONIO MOUNTAINS, NEVADA \\ By \\ W. E. Davis, F. J. Kleinhampl, and J. I. Ziony
}

\section{INTRODUCTION}

An aeromagnetic survey of the San Antonio Mountains, which contain the important silver district of Tonopah, was part of a geologic investigation of mineral deposits undertaken in the U.S. Geological Survey Heavy Metals program. The primary purpose of the survey was to define concealed masses of igneous rocks and determine their relation to metallic mineral deposits. An effort was also made to determine the magnetic environment of the known deposits. The San Antonio Mountains are especially adaptable for such a study because they lie at the southeast end of the Virginia City-Tonopah (Walker Lane) mineral belt hypothesized by Roberts (1966) and contain a variety of metallic deposits, including some of the richest silver ore discovered in Nevada.

The mapped area includes the San Antonio Mountains and bordering strips of Ralston and Big Smoky Valleys that lie between lat. $38^{\circ} 00^{\prime} \mathrm{N}$. and $38^{\circ} 25^{\prime} \mathrm{N}$. and long. $117^{\circ} 04^{\prime} \mathrm{W}$. and $117^{\circ} 22^{\prime} \mathrm{W}$. in Nye and Esmeralda Counties, Nev. Tonopah, the county seat of Nye County and famous in the past for its rich deposits of silver ore, is in the southern part of the area. The mountains form a northward-trending unit about 25 miles long and 6 to 8 miles wide with a prominent eastward bulge near the center, where it attains a width of 13 miles. A crest line of nearly 8,500 feet altitude and about 2,500 feet above the valley floors dominates the northern part of the range. The central and southern parts consist of uplands and isolated hills that rise abruptly out of a plain and reach altitudes of about 7,000 feet.

\section{GENERAL GEOLOGY}

Tertiary rocks crop out over most of the San Antonio Mountains, and Paleozoic and Mesozoic(?) rocks are exposed in three inliers. These are referred to as: (1) the Liberty-Hall inlier in the northwestern part of the mountains; (2) the Maggy Blues inlier on the eastern bulge of the range; and (3) the Rays inlier (from the mining site of Rays) north of Tonopah between Red and Lime Mountains.

The oldest rocks, chiefly dark-colored siliceous slate and argillite of the Ordovician Palmetto Formation, are exposed in the Maggy Blues and the Rays inliers. At the Rays inlier near Red Mountain, minor contact-metamorphosed strata, including gray marble and dark siliceous rocks of the Palmetto, crop out. Also, partly cross-stratified quartzite resembling that in the Cambrian Gold Hill Formation of ranges to the north is present at the ra-. dar site, but since the outcrop is small and the age uncertain, the strata are included with the Palmetto on the map. At the site of Rays, a thrust plate of a Mississippian limestone several hundred feet thick lies on dark siliceous strata assigned to the Palmetto Formation. North of Rays, the upper-plate Mississippian limestone is faulted against mudstone and shale of probable Mississippian age.

A similar Mississippian limestone also crops out in the LibertyHall area at a locality north of Florence Canyon. Faulted against, and perhaps partly beneath, this limestone is a sequence of calcareous to siliceous argillite, siltstone, and limestone that is believed to be Mississippian or younger in age. Dark-colored Permian(?) metasedimentary strata, chiefly siliceous siltstone, crop out widely in the vicinity of the Liberty mine farther south. An alaskite stock of probable Mesozoic age intrudes mica schist, sericitic quartzite, and silicified limestone at the Hall property, about a mile north of Liberty (Kirkemo and others, 1965, p. E75).
The intruded strata have no exact counterpart elsewhere except perhaps at the Florence mine and could be Mesozoic in age rather than Paleozoic as indicated on the map. Another pluton, a Mesozoic(?) porphyritic granodiorite, intrudes Ordovician strata near Red Mountain in the Rays inlier (Ferguson and Muller, 1949 , p. 51).

The Tertiary section, ranging in age from early(?) Miocene to Pliocene, includes rhyolitic to basaltic lavas, plugs, domes, and dikes; rhyolitic to dacitic tuffs and welded tuffs; and a sedimentary unit. The section is somewhat more than 5,000 feet thick where best known in the vicinity of Tonopah. Here the oldest Tertiary rocks are of Miocene (probable early Miocene) age and include rhyolitic, dacitic, and keratophyric material in welded ash-flow tuffs, air-fall tuffs, and flows of the approximately 2,500-foot thick Tonopah Formation (Nolan, 1935, p. 13-16; Broderick, 1949, p. 18; and Albers and Kleinhampl, 1970). Andesite lavas (chiefly the Mizpah Trachyte) about 2,000 feet thick overlie these tuffs and flows and are the main host for ore deposits in the Tonopah district.

The andesite lavas are overlain successively by the Fraction Breccia, a 745-foot-thick, quartz latitic, partly welded ash-flow tuff characterized by abundant lithic fragments; and the Siebert Tuff, consisting of more than 600 feet of fluviatile, deltaic, and lacustrine beds (Nolan, 1930, p. 21; 1935, p. 26; Spurr, 1905, p. 39, 51-54). A dull-reddish-brown, crystal-poor welded tuff about 500 feet thick was mapped with the Fraction because of its stratigraphic position above the Mizpah Trachyte north of Mount Ararat, but the tuff is now tentatively considered as an entirely separate unit.

Prominent hills near Tonopah, like Mount Oddie and Mount Ararat, are plugs of rhyolite that intrude the tuffs and andesite. Small scattered bodies of similar rhyolite and breccia pipes(?) intrude tuffs and older volcanic rocks in the extreme northern part of the San Antonio Mountains.

Other prominent isolated hills in the vicinity of Tonopah-such as Brougher Mountain, Mount Butler, and Golden Mountainare plugs and cumulodomes of the Brougher Dacite (Spurr, 1905, p. 44-47). These features form a north-south trend that extends along the west edge of the San Antonio Mountains from the Divide district south of town to about 8 miles north. Individual plugs at Tonopah, however, have crudely elliptical shapes with major axes trending east, a direction common tu the main orebearing veins of the district (Nolan, 1935, p. 11-12).

Porphyritic dacite(?) as much as 1,500 feet thick lies on and is locally faulted against pre-Tertiary strata and Tertiary tuffs in the northwestern part of the San Antonio Mountains. The porphyritic dacite(?) is partly intrusive as well as extrusive. Although its age is not well established, the unit appears to overlie felsic volcanic rocks tentatively correlated with the Tonopah Formation near Liberty and near the Cimarron claims and is in turn lapped by basalt correlated with a basalt at.Red Mountain that was described by Broderick (1949, p. 69-72).

The youngest fluidal rocks in the range are andesite and basalt flows that cap the crestal ridges and spread eastward to Ralston Valley: Several vent areas, marked by plugs and dikes, are widely scattered in the area underlain by these lavas. Red Mountain, together with some of the adjoining peaks on the southwest of the Rays inlier, appears to represent one such center. Here, considerable oxidation and vesiculation of the basalt has taken place, and basaltic tuff and agglomerate are locally abundant. Other eruptive centers are thought to exist along or close 
to the zone of faults that lies about 3 miles west of and parallel to part of Nevada Highway 8A. East of Cimarron, the capping basaltic rocks cut and are intercalated in their lower part with tuffaceous fine to medium clastic rocks that may correlate with the Siebert Tuff, a late Miocene and early Pliocene tuffaceous sedimentary deposit (Albers and Stewart, 1965). The flows and dikes are dominant in the higher part of the range but become less abundant in the lower peripheral part of the range, which suggests the major igneous source lies beneath the uplands.

Dikes of rhyolite porphyry and dacitic to andesitic porphyry commonly cut pre-Tertiary rocks in the Rays and Liberty-Hall inliers and intrude rocks as young as the Tonopah Formation near both areas. The more mafic dikes cut the rhyolite porphyry and are possibly consanguineous with the Mizpah Trachyte according to Broderick $(1949$, p. 26$)$. Because none of the dikes appear to cut the thick section of dacitic rocks at the north end of the range, the dacite probably postdates the Mizpah Trachyte and possibly is younger than the ore deposits at Tonopah.

The dominant exposed structure of the San Antonio Mountains is a series of elongate, slightly east-tilted blocks bounded by steep, north-striking normal faults downthrown on the west that displace stratigraphic units as young as Quaternary. More complex structural features, having lesser areal exposure, are evident in successively older rock sequences, with trends in the pre-Tertiary rocks strongly divergent from those in the Tertiary.

Pre-Tertiary rocks, exposed in the three inliers of the range, are highly folded and sheared, and commonly exhibit northwesttrending structural elements. Although large folds have not been mapped in these rocks, the complexity of bedding and foliation attitudes indicates that the strata probably are folded on a small scale; fold axes and (or) faults that trend northwesterly are suggested by the dominance of northwest-striking bedding and foliation surfaces in many places. The Permian(?) rocks of the Liberty-Hall inlier are said to form a west-trending syncline (Ferguson and Muller, 1949, p. 51) but this structure was not confirmed by the present authors. The Mesozoic(?) granodiorite pluton north of Tonopah is elongate in a northwesterly direction and is approximately concordant with attitudes of the enclosing Palmetto Formation, which suggests a structural control on its emplacement: At the Hall property, foliation in schistose rocks in general strikes northwestward, although a small alaskite stock is believed to have locally domed the surrounding metamorphosed strata into a northeast-plunging anticline (Kirkemo and others, 1965, p. E77).

Mississippian limestone at the Rays inlier has been thrust over the Palmetto Formation; the fault surface is subhorizontal and slightly irregular due to possible warping. Farther north in the range, near Florence Canyon, steeply dipping Mississippian strata may represent a remnant of the same thrust plate but are in contact with Permian(?) metavolcanic rocks. The age of the thrusting is presumed to be Mesozoic.

Tertiary strata older than the Fraction Breccia tend to be steeply inclined. At Tonopah, a complex pattern of faults (greatly generalized on the map) has been attributed by Nolan (1935, p. 39-40) to uplift and subsequent settling over a hypothetical intrusive beneath the district. Locally, at the south end of the Liberty-Hall inlier, older Tertiary welded tuff has been emplaced, perhaps by gravity sliding, on Permian(?) rocks along a low-angle fault.

The Fraction Breccia and succeeding stratigraphic units, although only slightly tilted, are cut by many high-angle normal faults which strike approximately parallel to the northerly trend of the San Antonio Mountains. Several such faults, indicated by a steep mountain front and by scarps in the alluvial fans, bound a large segment of the range on the west. Large displacements along the normal faults are confined primarily to the western and southern part of the San Antonio Mountains. Similar faults that have much smaller apparent displacements, and that locally may have been the loci for fissure eruptions, cut basaltic rocks on the east side of the range.

The trends of some intrusives of Tertiary age depart markedly from the general northerly strike of other young structural elements. Plugs of Brougher Dacite near Tonopah are elongate in an approximately east-west direction. Many Tertiary dikes within and just south of the Rays inlier, and in the southern part of the Liberty-Hall area, have northwest strikes. The orientation of these intrusives may reflect control on their emplacement by pre-Tertiary structural trends.

Rock alteration. - Several grades and kinds of rock alteration are present in the San Antonio Mountains. The most intense alteration is found in the mining districts, especially at Tonopah and the Hall property. Elsewhere, a lower grade, more pervasive alteration has affected some of the major stratigraphic units, particularly the Tonopah Formation and the Mizpah Trachyte.

Quartz-adularia-sericite alteration, chiefly superposed on albitized Mizpah Trachyte, is coincident with the central part of the Tonopah district and grades outward into a propylitic zone. The Hall molybdenum property is notable for extensive quartz veins and irregular silicification in alaskite and in adjacent sericitic quartzite, quartz-mica schist, and limestone. At the Cimarron claims, localized argillic and silicic alteration has been superposed on a more pervasive propylitic alteration of porphyritic dacite and small bodies of intrusive andesite. The limestone at Rays has been affected by massive silicification, especially along and near major steep faults and at contacts with Tertiary volcanic rocks. A contact-metasomatic zone in Paleozoic strata surrounds the granodiorite pluton near Red Mountain; dikes and irregular intrusive bodies of Tertiary age spatially associated with the granodiorite are commonly bleached and weakly argillized to intensely silicified.

Oxidized zones are extensive at all the mineral deposits, but sulfides are present at Tonopah and the Hall property, especially at depth. Pyritization of the Mizpah Trachyte is common in the Tonopah district; even the Fraction Breccia in the main part of the district is sparsely pyritized (Nolan, 1930, p. 21-22; 1935, p. 27).

The relatively pervasive alteration characterizing some of the older Tertiary units is best typified in the Tonopah Formation, the oldest Tertiary unit in the range. It is extensively altered by bleaching and by a generally pervasive, weak to intense, argillic to silicic alteration. The Mizpah Trachyte is weakly propylitized in most exposures. Other units may exhibit alteration over broad areas but cannot be described as pervasively altered; examples include the volcanic rocks mapped with the Fraction Breccia in the Maggy Blues area, which are commonly bleached and argillized, and the porphyritic dacite in the Cimarron locality. Field examination disclosed that weakly to intensely argillized dacite does not extend far south of Cimarron; therefore, the alteration may be more closely related to hydrothermal activity in the vicinity of the mines.

Mineral deposits. - A variety of metallic mineral deposits occur in the San Antonio Mountains. The most complete general description of the deposits is found in a report by Kral (1951, p. 157-161 and p. 169-174), from which the present authors have borrowed heavily for the brief descriptions given below.

Only silver-gold deposits have had major production, and most of this has come from the heart of the Tonopah district at Tonopah, where the Mizpah Trachyte of Miocene age is the host for silver-gold-quartz replacement veins along faults and fissures. The Divide district south of Tonopah yielded appreciable silver and gold from lodes in a host chiefly of Fraction Breccia intruded by andesite, latite, and rhyolite. Some production of gold and silver is believed to have come from quartz veins in Ordovician siliceous clastic strata in the Rays and the Maggy Blues inliers. Minor tungsten, as scheelite, occurs north of Tonopah (Peg Leg property) in contact-metamorphosed Paleozoic rocks that border the porphyritic granodiorite.

The San Antone (Cimarron) district in the northern part of the range includes: (1) the Liberty mine, a past silver and gold producer (from quartz veins in metamorphosed Permian(?) volcaniclastic rocks); (2) the Florence mine, a past producer of silver, with some lead and copper (from veins in siliceous and calcareous sedimentary rocks of Permian or Triassic age); and (3) the Cimarron properties, where gold occurs in rhyolitic to latitic breccia.

A little manganese was mined from shear zones in rhyolite 
south of Liberty, but the largest nonprecious metal deposit known near Liberty is at the Hall molybdenum property, about which C. Jay Parkinson, A naconda board chairman, says (Nevada Mining Assoc., 1969): "Available for immediate development are two important properties, ${ }^{* * *}$ and the other in the San Antone district, Nye County, Nevada, containing large tonnages of molybdenum-copper values lying close to the surface where openpit mining methods can be applied." More than a million tons of low-grade molybdenite here lies adjacent to the contact between an alaskite stock and metamorphosed clastic strata (Kirkemo and others, 1965, p. E73-E78) of Permian(?) age.

\section{AEROMAGNETIC SURVEY}

The survey was made with a continuously recording Gulf Mark III fluxgate magnetometer installed in a fixed-wing aircraft. Total-intensity magnetic data were obtained along eastwest traverses about 1 mile apart and flown at an average barometric elevation of 9,000 feet above sea level. Topographic maps were used for guidance, and the flight paths were recorded by a $35-\mathrm{mm}$ camera. Ground clearance ranged from less than 1,000 feet over the crest of the mountains to as much as 3,500 feet over the lowlands.

Magnetic features.-Prominentmagneticanomalies occur over the northern and southern parts of the San Antonio Mountains. The largest feature is a positive anomaly that reaches a maximum of about 300 gammas near Liberty Springs in the northwest part of the mountains. This anomaly occupies the western flank of the upland between the Cimarron claims and Lime Mountain, and includes a narrow strip along the east margin of Big Smoky Valley. It occurs mostly over porphyritic dacite(?), Tonopah Formation, and pre-Tertiary strata. On the northeast side of the anomaly, a narrow northward-trending arm coincides partly with a fault that placed dacite against basaltic rocks. Between the armlike anomaly and its parent main anomaly, an elongate narrow magnetic low continues southward over dacite along the mountain crest. A zone of low magnetic intensity lies over alluvium and Siebert Tuff at the north end of the mountains. Over the northeastern part of the range are negative anomalies that seem to be associated with basalt. To the south, pronounced negative anomalies also occur over basalt flows on the southeast flank of Lime Mountain and in the upland to the east. East of Red Mountain, a narrow magnetic high of low amplitude lies primarily over granodiorite and bordering rhyolitic rocks. The anomaly extends northeastward into the basalt-covered area south of Lime Mountain. A broad irregular zone of moderately high magnetic intensity overlies the remaining southern part of the range. This zone includes three major anomalies: (1) over Booker Mountain, (2) over the slopes and bordering lowland northwest of Tonopah, and (3) a broad, lowamplitude high centered over the hills southeast of Tonopah. The magnetic features are superimposed on a positive northeastward regional gradient of about 9.6 gammas per mile.

Interpretation. - The interpretation of magnetic features is based on results of geologic mapping and general knowledge of the magnetic properties of the rocks involved.

The major positive anomaly over the northwest part of the mountains probably represents a concealed mass of intrusive rock. Magnetic gradients indicate that the top of the mass is near the surface and underlies much of the volcanic rocks and older sedimentary strata exposed in the western foothills of the range. From the alinement of faults and magnetic maximum, we infer that the uppermost part of the anomaly source lies beneath a zone of major northward-trending faults. Laboratory examination of rock samples from the anomalous area indicates that Tertiary tuffs and pre-Tertiary strata near the Liberty and Hall properties are essentially nonmagnetic; and that the dacitic rocks in Florence Canyon and near the magnetic maximum are reversely magnetized. Eight oriented samples of the dacitic rocks have induced magnetization intensities ranging from $0.13 \times 10^{-3}$ to $0.82 \times 10^{-3} \mathrm{emu} / \mathrm{cc}$ and possess reversed remanent intensities of $1.11 \times 10^{-3}$ to $1.55 \times 10^{-3} \mathrm{emu} / \mathrm{cc}$. The direction and intensity of total magnetization in the dacites is such that they probably do not contribute much to the magnetic pattern. A few samples of the andesitic rocks have an induced magnetization range of $0.69 \times 10^{-3}$ to $2.51 \times 10^{-3} \mathrm{emu} / \mathrm{cc}$ and negligible remanent magnetization. The moderately strong magnetization intensities of some of these rocks and the occurrence of numerous andesitic dikes suggest that the anomaly is probably produced by an underlying large mass of intrusive andesite. The conspicuous node extending north ward from the east side of the main anomaly is considered to be the magnetic expression of a narrow concealed dikelike mass of the andesite, whose emplacement may be partly controlled by a north-trending fault.

The narrow north-trending low in the northern part of the mountains is attributed to volcanic rocks. Altered tuffaceous rocks (Tonopah? Formation) of low magnetic susceptibility account for the northern part of the anomaly near the Cimarron claims. A bout 1 to 2 miles farther south, reversed or abnormally directed remanent magnetization in rocks along the range crest may contribute to the anomaly. Porphyritic dacite, some altered, forms the outcrops here in the south part of the anomaly. These rocks, owing to their reversed remanent magnetization, could account for the southern extension of the magnetic low.

Remanent magnetization in basalt flows causes the extensive zone of low magnetic intensity over the eastern slopes and foothills between the Maggy Blues inlier and the range crest. Magnetic properties of a few samples of the basalts and the general low magnetic response of these rocks indicate that many of the flows are inversely polarized and that the directions of their total magnetic intensity are mostly antiparallel to the earth's magnetic field. The intensity of remanent magnetization measured for eight inversely polarized samples of basalt from three localities ranges from $3.75 \times 10^{-3}$ to $2.16 \times 10^{-3} \mathrm{emu} / \mathrm{cc}$. These samples have induced magnetization intensities of $0.19 \times 10^{-3}$ to $0.22 \times 10^{-3}$ $\mathrm{emu} / \mathrm{cc}$. Probable sources of local anomalies in the low-intensity zone are described below.

The broad magnetic low centered near the northeast edge of the upland lies over basalt and an underlying complex of tuffs, tuffaceous sedimentary rocks, and andesite dikes and flows. The magnetic expression of this sequence is probably dominated by the magnetic properties of the basalt. Very likely, the low is produced by a thick accumulation of basalt flows that form prominent spurs along the mountain front. About 4 miles to the south, a small negative anomaly marks a locally thickened reversely magnetized basalt.

Magnetic minimums over parts of the upland east and northeast of Lime Mountain may represent sources of the basalt flows. One such local source may underlie the broad minimum directly east of Lime Mountain, where there is a thick accumulation of basalt. The trend and size of the anomaly indicates that the source extends southward beneath the southeastern edge of the upland. Another prominent minimum to the northeast near the Maggy Blues inlier has greater negative amplitude but occupies only a small part of the basalt-covered upland. The circular shape of the feature is characteristic of a cylindrical mass and suggests that the source is a vertical volcanic plug surrounded by basalt flows.

A pronounced lineament, chiefly reflected in the distribution of magnetic anomalies, trends northeast and southwest from Lime Mountain and appears to persist across the entire range. To the northeast, the lineament is reflected as a discontinuity that separates prominent magnetic lows on the southeast from similar anomalies on the northwest. Steep faults along the north edge of the Rays inlier coincide with the lineament at its southwest end. These faults partly affect the young basaltic rocks, and, as suggested by the lineament, may represent a major structural break. Their trend, as well as that of the lineament, is alined with conspicuous faults along the eastern edge of the Toquima Range to the northeast. Because of the somewhat unique direction of these faults, continuity between the widely separated segments seems plausible.

The source of the weak magnetic high east of Red Mountain cannot be readily determined. Shape and trend of the anomaly suggest that its source is a narrow body which occupies the position of parts of the granodiorite and bordering volcanic rocks, 
and extends northward beneath a thin cover of basalt to near the southern slopes of Lime Mountain. Low induced magnetization intensities $\left(0.13 \times 10^{-3}\right.$ to $\left.0.26 \times 10^{-3} \mathrm{emu} / \mathrm{cc}\right)$ observed in samples of the granodiorite indicate that the plutonic rocks are not the main source of the anomaly. The anomaly maximum seems to be areally associated with mafic and rhyolitic dikes that cut rhyolitic volcanic rocks and the eastern part of the pluton. Very likely, the anomaly represents a substantial concealed mafic intrusive body, of which the outcropping mafic dikes are apophyses. Numerous outcrops of intermediate (dioritic?) dikelike masses that cut granodiorite just north of the radar site, approximately coincident with the anomaly maximum, tend to support this interpretation. Such high-density rocks could also be the source of a coincidental gravity maximum observed in a regional gravity survey by Erwin (1968).

Remanent magnetization in tuff (Fraction Breccia) and basalt flows, augmented by topography, is considered to be the source of the positive anomaly over Booker Mountain. Examination of a few basalt samples from the mountain crest indicates that here the flows are not inversely polarized and, therefore, may be of a different age than many of the basalts that exhibit a negative magnetic response. The basalt samples from Booker Mountain have an average induced magnetization intensity of $1.57 \times 10^{-3}$ $\mathrm{emu} / \mathrm{cc}$ and an average remanent intensity of $1.54 \times 10^{-\beta} \mathrm{emu} / \mathrm{cc}$.

Gradients of the positive anomaly northwest of Tonopah indicate that the source of the feature lies near the surface and is outlined in large part by the 2740-gamma contour. Crowding of the contours suggests that the south and west sides of the source are comparatively steep. Six samples of welded tuff (Fraction Breccia) near the magnetic maximum have induced magnetization intensities of $0.17 \times 10^{-3}$ to $0.22 \times 10^{-3} \mathrm{emu} / \mathrm{cc}$ and remanent intensities of $2.21 \times 10^{-3}$ to $4.81 \times 10^{-3} \mathrm{emu} / \mathrm{cc}$. The moderately strong remanent magnetization suggests that these rocks could be the source of the anomaly. However, their estimated thickness of 745 feet based on geologic data is not sufficient to account for the anomaly amplitude. Very likely the anomaly is caused by the tuff and underlying andesite lava (Mizpah Trachyt $\epsilon$ ), which also contains appreciable remanent magnetization. Possibly this anomaly represents the concealed pile of unaltered andesite lavas (Mizpah Trachyte) that are host for silver ore deposits in the Tonopah district (Nolan, 1935, p. 9).

The broad low-amplitude positive anomaly southeast of Tonopah is ascribed to an extensive mass of intrusive dacitic rocks (Brougher Dacite). The Brougher in this part of the area has moderately strong total magnetization intensities, in contrast to the surrounding tuff (Fraction Breccia), which appears to be highly altered and has negligible magnetization. It should be noted that the Fraction Breccia northeast and north west of Tonopah exhibits moderately strong remanent magnetization and is more densely welded and much fresher than the Fraction here south of Tonopah. From the anomaly we infer that dacitic rocks exposed on Mount Butler and the southeastern hills underlie tuff in the intervening lowland. Seven samples of the Brougher $\mathrm{Da}$ cite collected from three localities have a remanent magnetization intensity range of $1.28 \times 10^{-3}$ to $5.10 \times 10^{-3} \mathrm{emu} / \mathrm{cc}$. Their induced magnetization ranges from $0.10 \times 10^{-3}$ to $0.44 \times 10^{-3}$ $\mathrm{emu} / \mathrm{cc}$.

Magnetic features and mineral deposits. - The mining districts are in magnetically anomalous parts of the San Antonio Mountains; in addition, several metal-mine localities can be spatially related to inferred sources of magnetic anomalies. The magnetic environment of mining districts is expressed as magnetic highs and lows and accompanying zones of high magnetic gradients. The foregoing is not to say that magnetic anomalies are restricted to mining districts; neither are all mineral deposits related to magnetic anomalies, but a few of the latter may serve as targets for exploration.

Mines and prospects in the northwestern part of the San Antonio Mountains lie on the flanks of a prominent positive anomaly, and major workings, like the Liberty and Hall, could be near the edge of an andesitic intrusive body inferred from the anomaly. It must be emphasized that correlation of mineralized ground (indicated by mines and prospects) with the magnetic anomaly does not imply any direct genetic relation of mineral deposits and the inferred mafic source of the anomaly. Published descriptions and data obtained from examination of the deposits indicate, rather, that their origin is most likely related to more silicic and possibly older intrusives, such as the alaskitic to quartz monzonitic stock at the Hall molybdenum property. The possibility remains that the inferred mafic intrusive somehow directly or indirectly affected the localization or concentration of at least some of the mineral deposits, or may by its presence reflect a preexisting structurally weak zone along which earlier mineralized rocks were concentrated. Thus, the distribution of workings south and east of the Liberty mine and in Florence Canyon peripheral to the inferred mafic intrusive warrants close attention. Mineralized zones in the pre-Tertiary rocks may continue southward and northeastward along the margin of the anomaly. The maximum of the anomaly is interpreted to be the expression of the upper part of the intrusive body, which underlies faulted rhyolitic rocks (Tonopah Formation) and porphyritic dacite west of the mountain crest; because fault zones in the rhyolitic rocks near intrusive bodies are commonly mineralized, this locality also may warrant additional investigation.

The Cimarron group of claims in altered rocks of the Tonopah(?) Formation at the north end of the mountains coincides with the northern part of a narrow magnetic low. The trend of this low, and its association with altered rocks, suggests that an altered zone with ore potential may continue northward and southward beyond the mines.

The Midway mines, in the Palmetto Formation in the Maggy Blues area, are not marked by a magnetic anomaly. These mines are southeast of a magnetic low that is ascribed to a cylindrical plug of basalt considered to be younger than the ore-bearing veins.

Mineralized localities near Rays (site) are not expressed in the magnetic pattern but those near Black and Red Mountains partly coincide with the crest and flanks of an elongate positive anomaly. Despite this spatial relation, there is probably no close genetic association of mineral deposits and the inferred concealed mafic source of the anomaly. Mineral deposits here consist chiefly of tungsten in contact metamorphic zones bordering the granodiorite, and scattered gold(?)-quartz veins in the Palmetto Formation. South of the granodiorite intrusive, mine prospects lie in a magnetic low that is associated mostly with andesitic rocks that are commonly altered and weakly mineralized. The trend of this low coincides with the position and north-northwest trend of major faults that extend to the eastern edge of important mines at Tonopah. Very likely the magnetic low and rocks within the fault block to the south are favorable targets for prospecting.

The mines in the immediate vicinity of Tonopah are associated with the southeast flank of a conspicuous magnetic high and an adjacent weak low. The low in all likelihood corresponds to the center of intense alteration described by Nolan $(1935$, p. 42, 4547). The eastward trend of magnetic gradients forming the southern flank of the positive anomaly coincides with the trend of the main ore zone at Tonopah, and distribution of several of the mines suggests that some mineralized zones lie along the inferred southern margin of the source of the positive anomaly. Near Mount Ararat, north of Tonopah, mines and prospects lie adjacent to the Halifax fault zone that is marked by a magnetic low crudely indicated by irregularities in the magnetic contours on the east side of the major anomaly described above. One mine here, the King Tonopah, encountered rich mineralized rock and is significant because the locality is north of and outside the main productive zone at Tonopah. These factors support the contention of Nolan $(1935$, p. 49) that ground favorable for ore deposits lies north of the heart of the district.

South of Tonopah, several mines, especially those in the Divide district, occur near rhyolitic and dacitic intrusive bodies that coincide with the southwestern flank of a low-amplitude magnetic anomaly. The magnetic gradients suggest that the intrusive rocks and the spatially related mineral deposits are near the edge of the source of the anomaly. The western and southern flanks of this feature, therefore, appear to be reasonable explor- 
ation targets for additional ore deposits.

From the foregoing discussion, we may conclude that most of the mineral deposits lie on the flanks of magnetic anomalies, presumably along the margins of rock bodies causing the anomalies, and appear to be controlled by rock discontinuities, many of which represent structural boundaries.

\section{REFERENCES CITED}

Albers, J. P., and Kleinhampl, F. J., 1970, Spatial relation of mineral deposits to Tertiary volcanic centers in Nevada, in Geological Survey research, 1970: U.S. Geol. Survey Prof. Paper 700-C. In press.

Albers, J. P., and Stewart, J. H., 1965, Preliminary geologic map of Esmeralda County, Nevada: U.S. Geol. Survey Mineral Inv. Field Studies Map MF-298, scale 1:200,000.

Broderick, A. T., 1949, The geology of the southern part of the San Antonio Mountains, Nevada: Yale Univ. New Haven, Conn., Ph. D. thesis, $81 \mathrm{p}$.

Erwin, J. W., 1968, Gravity map of the Tonopah, Baxter Spring, Lone Mountain, and San Antonio Ranch quadrangles, Nevada: Nevada Bur. Mines Map 36, scale 1:125,000.

Ferguson, H. G., and Muller, S. W., 1949, Structural geology of the Haw thorne and Tonopah quadrangles, Nevada: U.S. Geol. Survey Prof. Paper 216, 55 p.
Kirkemo, Harold, Anderson, C. A., and Creasey, S. C., 1965, Investigations of molybdenum deposits in the conterminous United States, 1942-60: U.S. Geol. Survey Bull. 1182-E, p. E1-E90.

Kleinhampl, F. J., and Ziony, J. I., 1967, Preliminary geologic map of northern Nye County, Nevada: U.S. Geol. Survey open-file map, scale 1:200,000.

Kral, V. E., 1951, Mineral resources of Nye County, Nevada: Nevada Bur. Mines Bull., v. 45, no. 3, Geology and Mining Ser. 50, 223 p.

Nevada Mining Association, 1969, Newsletter, dated August 15, 1969: Reno, Nevada Mining Assoc.

Nolan, T. B., 1930, The underground geology of the western part of the Tonopah mining district Nevada: Nevada Univ. Bull. v. 24, no. 4,35 p.

1935, The underground geology of the Tonopah mining district, Nevada: Nevada Univ. Bull., v. 29 , no. 5,49 p.

Roberts, R. J., 1966, Metallogenic provinces and mineral belts in Nevada: Nevada Bur. Mines Rept. 13, pt. A, p. 47-72.

Spurr, J. E., 1905, Geology of the Tonopah mining district, Nevada: U.S. Geol. Survey Prof. Paper 42, $295 \mathrm{p}$. 